\title{
Lockean Money, Indigenism and Globalism
}

\section{NAOMI ZACK}

There are no nations, there are no peoples.... There is only one wholistic system of systems, one vast, interwoven, interacting, multivariant, multinational domain of dollars. It is the international system of currency which determines the totality of life on this planet. That is the natural order of things today.

\section{-Clarence Jenson}

Network, Metro-Goldwyn Mayer, 1976

When the seats of power and authority have been attained, there should be no more poetic license.

-J. M. Keynes

The term 'indigenism' is currently used to refer to the traditions, interests, and goals of the descendants of original, or "pre-contact," inhabitants of lands that Europeans and Americans invaded and exploited. ${ }^{1}$ In general, during the modern period, indigenist civilization has been oppressed by European civilization. Although liberatory critics have addressed the political and moral aspects of European colonial oppression, not much, at least by philosophers, has been written about the nature of money. Money was the nonviolent mechanism of land dispossession, which was the main material form of European oppression of indigenists.

1 There are several reasons why scholars and activists now find 'indigenist' preferable to 'native.' The term 'native' may be too broad insofar as anyone born in a nation could be called 'native.' If 'native' is used to specifically designate pre-contact natives, it carries derogatory connotations imposed by invading groups. The term 'indigenist' seems to best connote the land-based ethos of many contemporary inhabitants of dependent sovereign states. (See note 39, below, and the discussion of land-based economic issues in Section III of the text of this article.) 
John Locke was a chief architect of the modern system of money that was based on metallism or a gold and silver standard. An examination of the early modern European monetary system, proceeding from Locke's ideas, can deepen an historical understanding of the uneven opposition between European economic development and indigenism. The first part of this paper addresses the implications for indigenist land ownership of Locke's location of money in the state of nature. Part II is about the English monetary system of Locke's time and his ideas about money; Part III is an analysis of several conceptual issues involving monetary systems that are relevant to indigenist rights.

\section{Money and Ownership in Locke's State of Nature}

Recently, Locke's theory of original appropriation has been re-examined to determine whether it justifies European appropriation of land in the Americas, or supports prior indigenous ownership. Locke's claim that indigenist holdings and occupation had not removed American land from the common of humanity helps justify European appropriation, or at least does not render it unjust. ${ }^{2}$ But a broader interpretation of Locke that takes into account natural law principles of ownership and empirical information about indigenous customs may not justify European appropriation. For instance, John Douglas Bishop explains how, due to cooperative labour within clans and the absence of grazing animals, Iroquois at the time of European settlement recognized communal ownership of unenclosed land. Bishop argues that this custom, together with a concept of labour that includes restrained hunting, supports a view, derived from Lockean natural law, that indigenist people already owned land that Europeans thought they were "originally appropriating. ${ }^{3}$ Thus, given labour and improvement as a foundation for ownership, Locke could have recognized indigenist ownership of large parts of America.

2 See James Tully, 'Rediscovering America: The Two Treatises and Aboriginal Rights,' in Locke's Philosophy: Content and Context, ed. G.A.J. Rogers (Oxford: Clarendon Press, 1994); Naomi Zack, 'Locke and the Indians,' in The Social Power of Ideas, ed. Yeager Hudson and W. Creighton Peden (Lewiston, NY: Edwin Mellen Press, 1995). 
However, as C.B. MacPherson points out, Locke included money, as a store of value, in his description of conditions of original acquisition. ${ }^{4}$ Locke assumed that precious metals are universally valued (explicitly or tacitly) in conditions of original acquisition, and his proviso against waste contained a loophole that surplus products of land could be exchanged for precious metals. ${ }^{5}$ This in itself makes it unlikely that Locke would have recognized ownership where owners did not deliberately create surplus to be exchanged for precious metals. In the Second Treatise, Locke notes that without money, as was the situation in America, there would be little improvement of land:

For I ask, What would a Man value Ten Thousand, or an Hundred Thousand Acres of excellent Land, ready cultivated, and well stocked too with Cattle, in the middle of the in-land Parts of America, where he had no hopes of Commerce with other Parts of the World, to draw Money to him by the Sale of the Product? It would not be worth the inclosing, and we should see him give up again to the wild Common of Nature, whatever was more than would supply the Conveniences of Life to be had there for him and his Family. (II,V,48)

This passage suggests that enclosure and continued occupation are necessary conditions for land ownership. Money is also required as an incentive to prevent abandonment of otherwise valuable surplus

3 John Douglas Bishop, Locke's Theory of Original Appropriation and the Right of Settlement in Iroquois Territory, Canadian Journal of Philosophy, 27:3 (September 1997): 311-37.

4 MacPherson generally interprets Locke as having projected seventeenth-century English market conditions onto the state of nature. As will soon be evident, I agree with him that Locke located money in the state of nature. But the question that interests me in this paper is what Locke means by money. I will show in Section II that Locke's ideas about money in seventeenth-century England rest on the same principles of natural law that apply in his description of the state of nature. The philosophical examination of these principles means that Locke did not so much project conditions of his time onto a presumably earlier state of nature; rather he thought that the same principles governed both the state of nature and seventeenth-century culture. See C.B. MacPherson, The Political Theory of Possessive Individualism (Oxford: Oxford University Press, 1962), 197-222, 233-35.

5 References and quotes are from John Locke, Two Treatises of Government, ed. Peter Laslett (Cambridge: Cambridge University Press, 1991). 
land. On any theory of property, abandonment would signal the voluntary termination of ownership. Therefore, according to Locke, it would be impossible for indigenous people in America to own more land than they immediately used, because they did not use money. On those grounds, Locke's theory of original appropriation does justify European appropriation of indigenist land.

Locke may not have known that although indigenists had money, they chose not to accumulate it, and he may not have known about the existence of cultural systems that do not place a high value on the acquisition and accumulation of money. Perhaps, if he had known these things, he would have thought that indigenists did not have the kind of money that was valuable in itself, or that they lacked a monetary system capable of affording them those conveniences and luxuries that he believed human beings ought to labour to acquire.

Textually, Locke equivocated between 'money' in the sense of a precious object of exchange and 'money' as currency that is part of a national or international system of exchange. In the passages where he introduces money into the state of nature, he first talks about a person engaged in the simple exchange of goods that would otherwise spoil for precious objects:

If he would give his Nuts for a piece of Metal, pleased with its colour; or exchange his Sheep for Shells, or Wool for a sparkling Pebble or a Diamond, and keep those by him all his Life, he invaded not the Right of others, he might heap up as much of these durable things as he pleased; the exceeding of the bounds of his just Property not lying in the largess of his Possession, but the perishing of any thing uselesly in it. (II,V,46)

But after Locke goes on to imagine the abundant parcel of land that would be abandoned, for lack of the power "to draw money" to its owner in the "inland parts of America" (in II, V, 48, quoted above), he refers to money as currency in a wider system. Money in the second systematic sense is a way to own more land than one needs for its products and for some to own more land than others; and Locke maintains that these unequal effects of the use of money occur in conditions before government: ${ }^{6}$

6 See Naomi Zack, Bachelors of Science: Seventeenth Century Identity, Then and Now (Philadelphia: Temple University Press, 1996), 194-97. 
This partage of things, in an inequality of private possessions, men have made practicable out of the bounds of Societie, and without compact, only by putting a value on gold and silver and tacitly agreeing on the use of Money. (II,V,50)

Locke's location of money in the state of nature may be fair insofar as it was associated with acquisition due to labour. And it may be just, because God did not object to it. But, after original acquisition based on labour, subsequent acquisition could accompany sloth, and that would be unfair. And without God's authority, the location of money in a state of nature would be unjust, in the sense of inequitable, due to cultural differences. A monetary system gives to some members of communities that have it, advantages (in the form of more man-made goods, techniques and services) over members of communities that do not. This is particularly true when the communities with monetary systems have currencies translatable among each other and more military power than communities without monetary systems.

These oppressive effects of money were not considered by Locke because his paradigm owner was a European middle-class farmer. If his description of the state of nature is meant to be historical, his paradigm is simply an anachronistic projection from his own historical context. But suppose that his description of the state of nature is normative, because it provides a contract-theory template for justifying political society. In that case, Locke might have claimed that the majority of humankind would find the situation of a European middle-class farmer an ideal human situation, which would make his error(s) more complicated to pinpoint: Locke erred in universalizing that particular historical ideal and/or he erred in failing to consider that the inability of some to attain that ideal makes it unsuitable as a test for a just society, especially if the attainment of the ideal for some would require its unattainablity for others.

In connecting money to ownership, insofar as money was an incentive to improve, and thereby own, land, Locke overlooked important general cultural and historical alternatives to individual ownership based on continuously-worked enclosed parcels: land has been owned and worked by communities, with surplus products traded among neighbours; land has been owned with occasional use by owners who occupy it continually or intermittently; land has been owned for the purposes of hunting, fishing and recreation (including aesthetic appreciation). These are all types of situations in which land has been left in 
what Locke would consider a form of common, but ownership has nonetheless been recognized. (For example, in Locke's own day, European governments recognized indigenist ownership of land when they entered into treaties with indigenists; commons were owned by European peasants; and nobles owned vast tracts of land that had never been improved.) In addition, land and water (such as the oceans) have by consent been left in what Locke would consider their original common, without private ownership, throughout historical conditions that have followed the widespread use of money - either because such land would be too difficult to possess, or because it is owned by governments. (Locke was aware of this when he spoke of the ocean as "that great and still remaining Common of Mankind." See II,V,30.) Also, it is at least conceivable that parts of the earth might be left in common because they have intrinsic worth and ought for their own sake not be laboured upon, or otherwise interfered with, by human beings. ${ }^{7}$ Locke's historical assumption that money eliminates the common is therefore wrong. The historical facts generally seem to support a pluralistic model of the existence of commons and the existence of private property, both during and after the state of nature (or before and after the existence of civil government). Perhaps more to the point, against Locke, both commons and private property seem to have existed both before and after the existence of money and monetary systems.

These broad historical facts of the existence and nonexistence of money and government, intersecting with instances of private property and commons, make Locke's introduction of money and monetary systems into the state of nature appear normative. Locke can be reinterpreted, not as making factual claims about the effects of money, but as claiming that money and its use have social value. Locke referred to the nonuse of money and resulting lack of incentive to privately and individually own more land than needed for survival as a form of social isolation:

7 In Euro-American terms, this would be the position of 'deep ecology,' although respect for the intrinsic worth and right to be left alone of non-human natural entities has been an integral part of cultural practices and beliefs among indigenous people for eons. 
Yet there are still great Tracts of Ground to be found, which (the Inhabitants thereof not having joyned with the rest of Mankind, in the consent of the Use of their common Money) lie waste, and are more than the People, who dwell on it, do, or can make use of, and so still lie in common. Tho' this can scarce happen amongst that part of Mankind, that have consented to the Use of Money. (II,V,45)

It is not clear in this passage whether Locke means that those who do not use money are thereby, in some general and total sense, isolated from the productive majority of humankind, or whether they have merely not consented to the use of money but otherwise remain part of the constructive human community. There is a second, perhaps related, confusion concerning the value of money according to Locke. Is money and its pursuit valuable in principle or intrinsically, so that money justifies labour? Or is labour itself a primary value - because God intended humans to labour - and money therefore a secondary value because it is an incentive to labour? We know that Locke thought God gave humanity the earth and that human "wants" forced them to labour and appropriate (II,V,35); furthermore, God gave the earth to the use of "the rational and industrious (II,V, 34). If labour were a primary value, then ownership ought to accrue to those who labour, simply because they labour and not because they "draw money" to themselves. Although there is no direct textual answer to this question whether labour or money is the primary good, Locke would seem to be committed to the primary value of labour because he explicitly claims that God made it necessary for people to labour, and he does not explicitly claim that God commanded them to use and accumulate money. (Although there were writers in Locke's day who viewed money itself as a God-given human asset.) ${ }^{8}$ At any rate, I think it can safely be concluded that Locke posited money as a primary social institution, and a very good one. This raises the question of what Locke had in mind by money as a social institution.

8 John Ray, the naturalist, writing in 1691, believed that God had provided enough gold and silver to make trade possible. See Carolyn Merchant, The Death of Nature (New York: Harper and Row, 1980), 238, 246-48. 


\section{The Nature of Money According to Locke}

Today, we accept that money is a means for exchanging goods and services, as well as a measure of wealth, which is backed by political authority and supported by social convention. We live in immense and complex networks of paper currency, electronic money, and credit that have no intrinsic value. That is, our money is not otherwise materially precious. There has been no pretense that money symbolizes anything materially precious since the early 1970 s when the major countries of the West abandoned the gold standard. Without the gold standard, the major Western currencies are intrinsically worthless and they "float" against one another with no fixed rates of exchange. These currencies are all 'fiat money.'

For about two hundred years before the gold standard was abandoned, the major Western currencies were "backed up" by fixed quantities of gold and sometimes silver held by governments and central banks. This entailed that each unit of a currency had a fixed rate of exchange with units of other currencies because it represented a fixed amount of the same precious metal. Gold and silver themselves were also in a fixed quantitative ratio during any period of time. And, at least in principle, units of paper or base metal currency could be exchanged on demand for the precious metal they represented.

Furthermore, prior to this system of 'hard currency, all currency had intrinsic value. Thus, by 'money,' Locke did not mean paper or even coin that represented precious metals. He was referring to actual pieces of silver and gold, principally silver, because England was still on a silver standard during the second half of the seventeenth century. This intrinsically valuable nature of European money in Locke's day solemnifies the exclusionary anti-indigenist implications of his Second Treatise principles of land ownership.

Money, for Locke, could not have been 'only money,' and its pursuit and accumulation was a highly respectable activity, if not a moral

9 On the gold standard and its demise, see: Jennie Hawthome, Theory and Practice of Money (London: William Heinemann Ltd., 1981), 191-95; Jack Weatherford, The History of Money (New York: Three Rivers Press, 1997), chaps. 7-12, esp. 12. 
calling in its own right. His specific writings on interest rates and devaluation indicate that he believed there were important moral principles involved in protecting the existing intrinsic value of currency. One would expect those views to be consistent with natural law, if not actually derived from it, because Locke generally assumed that a just government preserved human society and did not contradict the principles of natural law. ${ }^{10}$

Locke developed his views on monetary policy as a political advisor in a complicated economic and monetary context. ${ }^{11}$ Space does not permit a detailed description of that context here, but the following conditions are directly relevant. During the late seventeenth century in England, there was a bimetal monetary system. Both silver and gold currency had fixed rates of exchange to each other and to silver and gold bullion. Real money was the existing coin in circulation, actual (silver) shillings and (gold) guineas, for example. Imaginary money consisted of the official units of currency that were used to keep accounts, for example, the terms 'shillings' and 'guineas' and the notations for them. Monetary crises resulted when the real money (actual currency) had less silver content than the imaginary or official money. Such discrepancy was mainly caused by the clipping off of parts of silver coins in circulation. When clipped coins were presented to the government in payment of revenue, or to the Mint for silver bullion, the government lost silver bullion in the exchange. The country also lost silver due to the export of coin and bullion as payment of expenses incurred in foreign wars.

The clipped coins in circulation drove unclipped coins into hoards. In foreign markets, the shilling was worth less than its official amount of silver in the English imaginary system. In England, gold sold for

10 A general example of Locke's reliance on natural law in this way is his claim that men have life, liberty, and property according to natural law and that their consent is therefore required for the existence of civil government (see in particular: Two Treatises, II, VIII, 119-22 and II, XI, 134 and 138).

11 For biographical discussion of Locke's political and economic posts and his involvement in monetary policy, see John Locke, Locke on Money, ed. Patrick Hyde Kelly (Oxford: Oxford Clarendon Press, 1991), vol. 1, 1-39. 
more (clipped) silver shillings than it did abroad for complete shillings. The complete coins were exported to buy gold abroad which could then be used to buy more shillings in England. (This eventual gain in silver could be doubled when clipped shillings were presented to the government for their full face amount.) As silver currency lost value, the market exchange rate between gold and silver coins favoured gold coins, creating a discrepancy between the real gold-silver coin ratio and the official one. Both the debasement of silver coins and their scarcity had a stagnating effect on domestic trade and caused prices of goods to rise. The scarcity of currency made business investment difficult and created pessimism about profits. Immediate monetary crises were perceived to be located in the shortage of real money because the economy was based on real money (cash).

Several solutions to these problems were proposed and debated: pass laws lowering interest rates to facilitate investment; devalue the currency or "raise the coin" so that the imaginary money corresponded in silver content with the real money; control the price of guineas to discourage speculation; punish clippers and counterfeiters more severely; recoin the currency as milled coins that could not be clipped; revalue the clipped currency in circulation, based on its actual silver content, so that, for example, a clipped shilling would be worth less than an intact shilling. ${ }^{12}$

Locke was against lowering the interest rate, ${ }^{13}$ against devaluation, ${ }^{14}$ in favour of revaluation of clipped coins at their actual weight in silver, ${ }^{15}$

12 As in the discussion of Locke's economic posts, I am here mainly relying on Kelly's Locke on Money. See 39-67. See also Sir John Craig, Newton at the Mint (Cambridge: Cambridge at the University Press, 1941).

13 John Locke, Some Considerations of the Consequences of the Lowering of Interest and Raising the Value of Money, in Locke on Money, vol. 1.

14 Further Considerations Concerning Raising the Value of Money, in Locke on Money, vol. 2.

15 Further Considerations Conceming Raising the Value of Money Wherein Mr Lowndes's Arguments for it concerning An Essay for the Amendment of the Silver Coins, are particularly Examined, 1695, in Locke on Money, vol. 2, 418-19. 
in favour of recoinage, ${ }^{16}$ in favour of making clipping unprofitable by making clipped coins unacceptable in trade and revenue, ${ }^{17}$ and in favour, in principle, of not controlling the shilling price of gold guineas. (He relented on this issue for practical purposes.) ${ }^{18} \mathrm{His}$ views are consistent with one another, and the arguments he gives for them are consistent with his theory of natural law, although the assumptions and development of Locke's monetary arguments are more sophisticated than the concrete and survivalist conditions he adduces when talking about the state of nature.

While Locke merely stated that money had intrinsic value in The Second Treatise, he explains 'intrinsic value' in Some Considerations of the Consequences of the Lowering of Interest and Raising the Value of Money. The intrinsic value of gold and silver money is imaginary, based on widespread consent that the metals themselves be accepted as money because of their durability, scarcity, and difficulty to counterfeit. ${ }^{19}$ The intrinsic value of these metals is their function as pledges to procure other goods by their quantity alone:

Now money is necessary to all ... sorts of Men, as serving both for Counters and for Pledges, and so carrying with it even Reckoning, and Security, that he, that receives it, shall have the same Value for it again, of other things that he wants, whenever he pleases. The one of these it does by its Stamp and Denomination; the other by its intrinsick Value, which is its Quantity.... The intrinsick Value of Silver and Gold used in Commerce is nothing but their quantity. ${ }^{20}$

16 John Locke, 'A Paper Given to Sir William Trumbull Which was Written At His Request September 1695,' in Locke on Money, vol. 2, 367-69.

17 Locke believed that the solution to the currency shortage and the crimes that caused it were the same. "There is therefor no sure way to put an End to Clipping but by makeing Clipping unprofitable and so it will be as soon as your money goes only for as much as it weights." Locke on Money, 369.

18 For Locke's free market views, see Some Considerations, in Locke on Money, vol. 1, 323-28 and 'Guineas,' in Locke on Money, vol. 2, 363-64; for Kelly's analysis of the immediate situation of depressing the guinea price, see Locke on Money, vol. $1,33-34$.

19 Locke, Some Considerations, in Locke on Money, vol. 1, 233.

20 Some Considerations, in Locke on Money, vol. 1, 233-34. 
We see here a crucial difference between Locke's Second Treatise introduction of money into the state of nature, as a "piece of metal" with an agreeable color or a "sparkling pebble" to be kept over a lifetime (II,V,46), and his economic definition of money as a notational symbol that facilites business and trade. Nonetheless, Locke's notational definition of money does not mean he thought that accounts could be kept in an arbitrary way, or that even the government could effectively influence the terms of financial transactions. Rather, the abstract nature of money seems to have facilitated precision about what could and could not be done with it. (We can also be assured that in the seventeenth century, as today, "quantity" meant "an amount" that in a mathematical sense could be operated upon "according to fixed mutually consistent laws." Locke's use of "intrinsick" was also the same as ours.) $)^{21}$ Locke defended what we would call hard currency and deflationary monetary policies as though they expressed inviolable scientific laws that were at the same time moral laws, that is, as though they were instances of natural law.

Locke argues empirically against lowering the interest rate but his arguments are based on his first principles of political philosophy from the Second Treatise. He reasons that borrowed money is like any other commodity in that its price is determined by money in circulation and the need for it. Therefore, if rates are artificially lowered, they will in fact continue to be determined by the scarcity of money and the amount of money available to pay for borrowing it. Those who break the law will find a way to increase rates beyond a natural market increase due to demand so as to make up for the risk they take in breaking the law. The market forces and actual transactions will continue to go on according to their own exigencies. As a result, people will be forced to perjure themselves on a widescale basis and the attendant guilt and temptation will result in widespread confusion that will make it "impossible for the Society (these Bonds [of truth and trust] being dissolved) to subsist." 22 In this regard, Locke thinks it is the duty of

21 See The Oxford English Dictionary: A New Dictionary on Historical Principles, ed. James A.H. Murray (Oxford: Oxford Clarendon Press, 1933), s.v. quantity and intrinsic.

22 Locke, Some Considerations in Locke on Money, vol. 1, 213. 
lawmakers not to make penalties for perjury more severe, but to minimize the temptations to it. ${ }^{23}$ This argument, which places custom and the well-being of society above the authority and rightness of positive law, is evocative of his Second Treatise theme that society is prior to, and its well-being more important than, government. "The first and fundamental natural Law, which is to govern even the Legislature itself, is the preservation of the Society, and (as far as will consist with the publick good) of every person in it" (II, XI, 134).

Locke also addresses the possibility that a law lowering interest rates will be obeyed. He argues that an artificially lowered rate would be bad for the nation because it would discourage foreign investment. This in turn would lessen the balance of trade for England. According to Locke, a favourable balance of trade meant very simply that more silver and gold (i.e., more money) would be imported than exported. This favourable balance could not be reckoned simply in more goods exported than imported, because the goods would ultimately be valued in money. And neither could a favourable balance be reckoned in credit because credit was nothing more than an agreement for debtors to pay money (i.e., bullion) ${ }^{24}$

The simplicity of Locke's mercantilist model proceeds directly from an extended example he gives of the financial health of a family farm: ${ }^{25}$ A thrifty father builds up a fortune by consistently spending less money on commodities at the market than what he gets for his "Cattle, Corn,

23 Locke, Some Considerations, in Locke on Money, vol. 1, 212.

24 See Some Considerations, in Locke on Money, vol. 1, 267-69, and Further Considerations, in Locke on Money, vol. 2, 420-22. Locke generally does not seem to have considered that credit, in the form of guaranteed promissory notes or bills of exchange, could and did function as money in circulation:

For noething will pay debts but mony or monys worth, which three or fower lines writ in paper cannot be, for if they have an intrinsick value and can serve instead of mony, why doe we not send them to market instead of our cloth lead and tin? (Locke, Final MS draft of Some Considerations, in Locke on Money, vol. 2, 521)

25 See Lars Magnusson, Mercantilism: The Shaping of an Economic Language (London: Routledge, 1994), esp. on Locke, 128-30. 
Butter, Cheese, Wooll or Cloth, Lead and Tin." His son and heir, who has extravagant tastes, does the reverse, to his eventual ruin. And, Locke concludes, "A Farm and a Kingdom in this respect differ no more than as greater and less." 26

Locke's position against devaluation or raising the coin rests on the presumption that the coin, or silver money, has intrinsic value due to its silver content. But keeping in mind his definition of "intrinsick value" as quantity, it turns out that his intention is to preserve a sameness of quantity in a sense that is analytic.

During the 1690 s, clippers had depleted the silver content of real money (i.e., money in circulation) by about a third, and speculators profited by exchanging light coin for full-weight coin at the Mint. Besides the loss to the government, the result was a shortage of money in circulation, a lack of confidence in the currency, and higher prices, especially in gold coin and bullion. ${ }^{27}$ William Lowndes, Secretary of the Treasury, proposed that the silver content of coin in circulation be lowered by law to accommodate the de facto devaluation, bringing full-weight coins out of hoards and alleviating the crisis. Locke was instrumental in defeating Lowndes's proposal through his arguments in Further Considerations. Their actual dispute is not very interesting insofar as it turned on a semantic difference: Lowndes defined money as real money in circulation and Locke defined money as official money. Therefore, Lowndes thought that gold and commodities derived their value from the silver content of the money in circulation that was paid for them, that is, their price in (actual) clipped coins, whereas Locke insisted that value was determined by prices commanded in fullweight coin, that is, specified (imaginary) coin. ${ }^{28}$ Thus, Lowndes thought that the value of silver was determined by amounts of money

26 Locke, Some Considerations, in Locke on Money, vol. 1, 231.

27 For economic and historical explanations of these events, see: Constantine George Caffentzis, Clipped Coins, Abused Words and Civil Government: John Locke's Philosophy of Money (Brooklyn, NY: Autonomedia, 1989), 17-44; Locke on Money, vol. 1, 39-67.

28 Locke, Further Considerations, Locke on Money, vol. 2, 428-55. 
and Locke thought that the value of money was determined by amounts of silver.

The basis on which Locke defended a revaluation of clipped coinage, according to its actual weight in silver, further clarifies his definitions of money in Some Considerations. First, Locke insisted that silver was the universal money, based on "common consent" to its use in trade. Furthermore, "[s]ilver is the measure of commerce by its quantity, which is the measure also of its intrinsick value."29 Coinage of silver by government does nothing more than guarantee its quality and quantity. Because silver is the common measure of all other commodities, and the only such measure, clipping is a crime (both robbery and treason) and the terms of exchange cannot be influenced by decreeing that a coin of a certain denomination will be worth a different amount of silver than it was previously decreed to be worth. If the coin is raised or devalued in its silver content, domestic creditors and renters will unjustly be paid less silver than they contracted for, and foreign traders will simply translate the revalued currency into its silver content and adjust their prices according. The only way that money in a nation that has no silver mines can be increased is if the value in silver of exports is greater than the value in silver of imports. ${ }^{30}$

If we keep in mind Locke's continual repetition that the intrinsic value of silver is its quantity, his claims amount to this: Based on consent to use silver as money and government oversight of the quantity and quality of silver in denominations of coin, the ratio of any denomination of coin to silver bullion ought to be a constant. This constant was an absolute for Locke:

The Standard once settled by public Authority, the quantity of Silver establish'd under the several denominations, (I humbly conceive) should not be altered, till there were an absolute necessity shewn of such a change, which I think can never be. ${ }^{31}$

29 Locke, Further Considerations, Locke' on Money, vol. 2, 410.

30 Locke, Further Considerations, in Locke on Money, vol. 2, 410-25.

31 Locke, Further Considerations, in Locke on Money, vol. 2, 415. 
Locke did not think that silver had any value in itself, as a special substance, although its durable properties of purity, consistency, portability, malleability, and so forth made it convenient as a measure of all other goods. It is also clear from his argument that he assumed the sphere of trade to be factually and morally independent of government:

Raising of Coin is but a specious word to deceive the unwary. It only gives the usual denomination of a greater quantity of Silver to a less, (v. g. calling four Grains of Silver a Penny to day, when Five Grains of Silver made a Penny yesterday) but adds no worth or real value to the Silver Coin, to make amends for its want of Silver. That is impossible to be done. For it is only the quantity of the Silver in it that is, and eternally will be, the measure of its value..$^{32}$

\section{Money and Indigenist Critical Issues}

If we put together the importance Locke placed in The Second Treatise on gold and silver money for ownership in the state of nature with his insistence on a constant silver standard for silver money in the English economy, the result is a closed system. Money is necessary to own land that will produce surplus goods that will be exchanged for money that can be used to buy man-made goods that will provide incentive to create more such goods. The medium for all such trade is money in circulation. Some of the money in circulation will go into investment in land, to be rented out for income in money. Indeed, as C.B. MacPherson notes, Locke equates land and money because both can be lent to produce income, or money, from "tenants." ${ }^{13}$ The aim of all trade, be it between a farm and the outside world or a nation and other nations, is to end up with a positive balance of money. Along the way, conveniences, luxuries, and varied social activities would doubtless be enjoyed, but all of these goods are desirable due to their location in the system of money-trade-money.

32 Locke, Further Considerations, in Locke on Money, vol. 2, 416.

33 MacPherson, Possessive Individualism, 206 (and n. ibid referring to Some Considerations, 6th ed. in Locke's Works, 1759, ii. 19). 
Money, which for Locke was silver, is intrinsically valuable. But intrinsic value for Locke means nothing more than quantity or the ability to be used as a constant measure of exchange. This is particularly the case when the ratio between coin denomination and silver content is invariable over time, as Locke insisted it should be. It would seem, therefore, that the end of all serious human endeavour can be reduced to a positive balance in an ongoing notational system. The mechanism of trade, facilitated by money and motivated by a desire for profit ultimately to be measured in money - is the dynamic force in the system: "Trade then is necessary to the producing of Riches and Money necessary to the carrying on of Trade. ${ }^{\prime \prime 34}$

Of course, Locke's economic writings are not the last word on Western monetary systems and neither do they tell the whole story. There are libraries of economic theory between Locke and Keynes; and, between the fiat monetary climate we live in today and Locke's time, there is a history of over two hundred years of the gold standard. ${ }^{35}$ Nonetheless, Locke's ultimate focus on money as nothing more than an accounting system has an eerie resonance with the economic ethos of contemporary multi-national corporations. What counts in corporate contexts is not community well-being, employment among the

34 Locke, Some Considerations, in Locke on Money, vol. 1, 223-24.

35 Twentieth-century fiat money is not backed up by precious objects but merely proclaimed to be money by government decree. However, there is an uncanny inversion between Locke's explanation of the intrinsic value of gold and silver and what fiat money apologists have said about intrinsic value. Locke claimed that gold and silver money has intrinsic value because it is pure quantity, whereas the chartalists have claimed that no money has intrinsic value because all money is pure quantity. Thus, the real issues in both cases have been whether certain equations ought to be changed or not. In Locke's day it was an issue of whether the equations between units of precious metals and money ought to be changed; in our century it has been a question of whether the equations between units of money and units of goods - which is to say, prices - ought to be changed by changing the money supply. (For discussion of these issues, see for example, $\mathrm{S}$. Herbert Frankel on the issues introduced by John Maynard Keynes, in Frankel, Money: Two Philosophies: The Conflict of Trust and Authority [Oxford: Basil Blackwell, 1977], 57-85, esp. 71-72.) 
citizens of one country or another, quality of goods, quality of environment, quality of human life, but the bottom line: Is the company making a profit in terms of its purely quantitative notational system (which by widespread consent is now reckoned in dollars)?

There have been models for human systems, both before and after the existence of civil government, that do not use accounting to reckon ultimate value as in the Lockean imaginary. And even within that imaginary, people have private and public values apart from the monetary "bottom line." Nonetheless, historically, money as an international medium of exchange provided the motive and mechanism for the appropriation of indigenist property in the Americas, as well as that of 'commoners' in Europe; it was also the principal motive and mechanism of colonial rule and chattel slavery. (Money in this sense has also worked as a medium of dispossession for twentieth-century farmers, in "in-land America" as well as the third world. Thus, Locke's belief that the property rights of individuals are secured through monetary systems has turned out to be naive. ${ }^{36}$

Many writers have stressed the fact that non-whites and non-Europeans have been most severely victimized by the European and later, American, economic system ${ }^{37}$ However, if the modern concept of race had never been invented there is no reason to believe that the modern Western monetary system would have worked any differ-

36 Loss of tand because the surplus produced on it is not enough to finance other necessities of life or to finance the market value of the land (which is borrowed when the land is mortgaged) could be a case in which farmers do not own their land to begin with, or have miscalculated in putting that ownership at risk. What would Locke have said about farmers in present "third-world" countries who lose land, livelihood, and even life because their governments first allow imports of foodstuffs at cheaper prices than can be offered domestically and can neither compensate the farmers after the imports rise in price nor buy enough imported foodstuffs to feed their populations? For a quick overview on present free trade agreements and their effects on small agricultural producers, see Kristin Dawkins, Gene Wars: The Politics of Biotechnology (New York: Seven Stories Press [The Open Media Pamphlet Series], 1997).

37 See, for instance, Charles Mills, The Racial Contract (Ithaca: Cornell University Press, 1997), 9-40. 
ently. ${ }^{38}$ For cogent criticism of this system, the first tradition that suggests itself is Marxism.

However, Marxist criticism does not do full justice to the clash between Western monetary society, which includes Euro-American trading partners in Asia and Africa, and indigenist cultures. Marxist economic analyses of oppression are, despite the international dimension of labour, not sufficiently international or more precisely, intersystemic. Most of the disadvantaged and oppressed in industrial and post-industrial nations - groups that include the working poor, members of the "underclass," the homeless, and non-white minorities who have suffered economic discrimination due to racial designation have material problems that could be substantially solved if they had more money. To some extent, the same can be said of women, homosexuals, the aged, and other groups who experience oppression based on what the dominant (white male group) perceives to be some kind of biological difference from itself. These groups are all therefore part of the Euro-American money-trade-money system.

But there are disadvantaged and oppressed groups whose material problems would not be solved with more money. Unlike labourers, homeless, non-whites, women, homosexuals, and the aged who are part of the Western monetary system but do not have enough money (or opportunity to get more), many indigenists have not fully belonged to the Western monetary system, and a good part of their ongoing struggle for recognition of their sovereign rights involves resistance to that system.

Ward Churchill, Russell Means, and Vine Deloria, Jr., have all argued forcefully against the applicability of Marxist analysis to the property rights of land-based peoples and to their cultural situations. Churchill points out that the Marxian "New Left" has failed to address indigenous rights in its twentieth-century political polemics and 'praxes.' One telling issue is a silence on the part of anarchists about

38 Colonialism and the slave trade were well underway before the biological concept of race had been developed. See Naomi Zack, Bachelors of Science: Seventeenth Century Identity, Then and Now (Philadephia: Temple University Press, 1996), chap. 12. 
policy toward treaty law in the advent of the demise of Western capitalist government. Another immediate American indigenist concern voiced by Churchill and others is the general Marxist presumption that technology will ultimately solve all material and environmental problems. This presumption ignores indigenist demands for environmental integrity that call for less rather than more extraction of natural resources from American Indian lands. ${ }^{39}$ Russell Means argues that Marxism itself is a development within the Western abstract project that can only solve problems within EuroAmerican society. ${ }^{40}$ Vine Deloria questions the applicability to indigenous society of the Marxist concept of the alienation of human beings from the world. ${ }^{41}$ Deloria's analysis is underscored by Frank Black Elk's description of the absence of divisions corresponding to Euro-American social class in the Lakota tradition..$^{42}$ Black Elk's contrast comes down to the importance of money in the Euro-American tradition:

It's all a matter of the "will" and ability to accumulate material; the standard also indicates a need to constantly arrange and rearrange material. The standard of measure seems to me to be that the more compulsive a culture can become in terms of gathering up and rearranging material, the more "advanced" it is considered to be. The more relaxed, at peace, and willing to leave material things (beyond real needs) alone a culture can be shown to be, the more "backward" it is considered. ${ }^{43}$

The challenge presented by the inadequacy of the Marxist critique in addressing indigenist claims of injustice is to find conceptual ways

39 See Ward Churchill, 'Introduction,' 1-16, and 'Marxism and the Native American,' 183-203, in Marxism and Native Americans, ed. Ward Churchill (Boston: South End Press, 1983).

40 Russell Means, 'The Same Old Song,' in Marxism and Native Americans, 19-33.

41 Vine Deloria, Jr., 'Circling the Same Old Rock,' in Marxism and Native Americans, 113-36.

42 Frank Black Elk, 'Observations on Marxism and Lakota Tradition,' in Marxism and Native Americans, 137-57.

43 Black Elk, 'Observations,' 144. 
of explaining the gap between indigenist and Euro-American material values. Given the importance of money in the Euro-American system, an adequate global model of political entities that exist in the world, which postulates equal rights for those entities, would have to specifically account for differences in monetary systems. The inclusion of indigenist political systems in such a model would require adjustments that would protect the economic vulnerabilities of indigenist to non-indigenist systems. If monetary systems are not mentioned in models for global justice, then money will continue to seep out of the EuroAmerican system as the main instrument of its expansion at the expense of indigenist land-based systems. (And if indigenist political systems are excluded from the global model, the model is not just.)

Max Weber's distinction between formal and substantive rationality may be of some use here. Formal rationality pertains to the calculations made within a monetary system by the producers of goods, given demand. Substantive rationality pertains to the relationship between the distribution of goods to members of a system and nonmonetary cultural values that include equal distribution of the necessities of life and equal opportunities to acquire goods. ${ }^{44}$ If we move to a more abstract level that encompasses different economic systems, we could say, first, that full participation in the Western monetary system is not substantively rational to members of many indigenous nations because it conflicts too strongly with their other cultural values. Second, the substantive rationality of the entire global system, encompassing both indigenist and Western nations, requires that the Western monetary system not be imposed on indigenous nations. That is, the diverse substantive monetary rationality of nations would have to be accepted and protected on a model of just global monetary pluralism.

Speaking very generally, the main difference in substantive rationality between indigenous and Western nations would seem to be the cultural value placed on trade with individuals and entities outside the nation in question. Western nations assume that external trade is

44 Max Weber, The Theory of Social and Economic Organization, trans. A.M. Henderson and Talcott Parsons (New York: Oxford University Press, 1947), 211-12. 
an important part of their economic system. If indigenous nations do not place the same value on such trade, they therefore, on those grounds alone, have less need for that "universal" medium of exchange which is money. In many cases, the money of Westerners functions destructively within indigenous land bases, especially when Western money can be used to acquire parts of those land bases and especially when alienation of communally owned property has and would continue to violate core non-monetary cultural values. It might therefore be helpful to the political cause of indigenous liberation if leaders gave more consideration, first to the exclusion of Western money from their own cultural transactions, and second to demands that this exclusion, and its consequences, be recognized by non-indigenist governments. ${ }^{45}$

We should now go back to that ambiguous passage of Locke's regarding money and humanity:

Yet there are still great Tracts of Ground to be found, which (the Inhabitants thereof not having joyned with the rest of Mankind, in the consent of the Use of their common Money) lie waste, and are more than the People, who dwell on it, do, or can make use of, and so still lie in common. Tho' this can scarce happen amongst that part of Mankind, that have consented to the Use of Money. (II, V,45)

The ambiguity of whether he meant that those who had not consented to the use of money were thereby not part of the human order, or merely not part of the monetary order, can be settled on a normative global model. Those who have not consented to the use of the

45 This might be easier to do insofar as contemporary Western money no longer has the form of otherwise precious objects, nor purports to represent such objects. Although, even when it was in such such form or symbol, it was unlikely to be as highly valued within indigenist cultures as it was in the West. Thus, Frank Black Elk writes:

I mean, consider the implications of a tradition which compels its people to march across half a continent, engage in a major war to steal the land from my people, engage in genocide in order to preserve their conquest, and all primarily so they can dig gold out of a small portion of that land, transport it back across the continent, and bury it again at Ft. Knox! The virulence of the disease Sitting bull spoke of is truly staggering. ('Observations,' 145) 
Western monetary system are part of the human order and their nations part of the national order, although neither they nor their nations are part of the monetary order. Insofar as the monetary order is based on consent, the monetary order should not be imposed on those who have not consented to it. Returning to the introductory remarks in this paper and to the theme of the volume, the monetary order is a facet of Western civilization that operates as a mechanism of oppression whenever it is imposed on other civilizations without their consent. Of course, it may also be oppressive within its civilization(s) of origin, but that is another matter. 